\title{
DETHRONING LEAR? INCENTIVES TO INNOVATE AFTER MEDIMMUNE
}

\author{
By Rochelle Cooper Dreyfuss ${ }^{t}$ and Lawrence S. Popet
}

\section{TABLE OF CONTENTS}

I. MEDIMMUNE AND ITS RAMIFICATIONS FOR LAW,

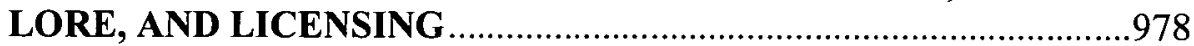

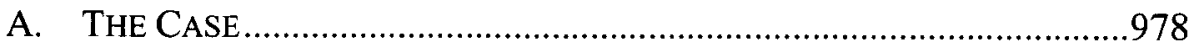

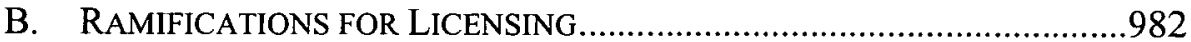

C. RAMIFICATIONS FOR PATENT LAW AND LORE .................................984

II. FIVE APPROACHES TO LICENSING IN LIGHT OF MEDIMMUNE

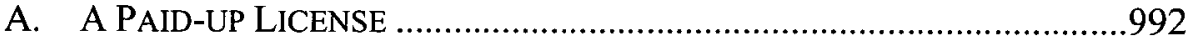

B. A LICENSE COUPLED WITH A CONSENT DECREE ..............................996

C. AN ARBITRATION CLAUSE ...............................................................999

D. A ClaUSE ADJUSTING THE ROYALTY EITHER TO REFLECT OR

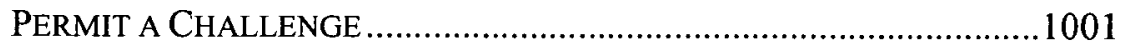

E. A TERMINATION-ON-CHALlENGE ClAUSE ....................................1003

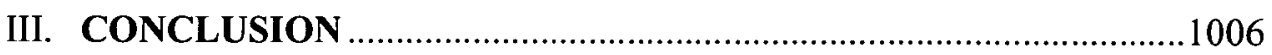

In January 2007, the U.S. Supreme Court radically changed the rules on licensing U.S. patents to the substantial disadvantage of anyone hoping to derive reliable revenues from the extraction of royalties. At the time of the decision in MedImmune v. Genentech, ${ }^{1}$ the law was fairly wellestablished: a licensee in good standing - that is, a licensee who was not in breach of its licensing agreement and therefore not at risk of having the license terminated-was barred from challenging the validity of the licensed patent. ${ }^{2}$ To gain access to federal court, such a licensee had to

(C) 2009 Rochelle Cooper Dreyfuss \& Lawrence S. Pope.

$\dagger$ Pauline Newman Professor of Law, New York University School of Law. The author wishes to thank Michael Risch for his thoughtful comments, Andrew Michaels, NYU Law School, Class of 2010 for research assistance, and the Filomen D'Agostino and Max E. Greenberg Research Fund for financial support.

$\ddagger$ A solo practitioner. Comments welcome at lawrences2005@yahoo.com.

1. MedImmune, Inc. v. Genentech, Inc., 549 U.S. 118 (2007).

2. See, e.g., Gen-Probe Inc. v. Vysis, Inc., 359 F.3d 1376 (Fed. Cir. 2004); Cordis Corp. v. Medtronic, Inc., 780 F.2d 991 (Fed. Cir. 1985). 
create a "case" or "controversy" 3 by committing a breach of the agreement, usually by withholding royalties. In MedImmune, however, the Supreme Court opened the federal courthouse doors to licensees in good standing by allowing them to bring declaratory judgment actions challenging patent validity.

In many ways, the decision in MedImmune v. Genentech is unsurprising. It is consistent with the Court's view on justiciability more generally and with the availability of declaratory relief in other legal contexts. ${ }^{4}$ The decision also resolves tensions with other procedural rules for patent litigation. ${ }^{5}$ For example, it has long been clear that a licensee in good standing can bring a declaratory judgment action to resolve a dispute on whether a given product or activity falls within the scope of the claims of the licensed patent. ${ }^{6}$ Since disputes about patent scope often trigger questions of validity, the distinction drawn in the pre-MedImmune era was always somewhat illusory.

As important, the Supreme Court recently expressed substantial concern about the strength and prevalence of patents. In the last three Terms, it raised the standard of inventiveness, ${ }^{7}$ limited the patentee's right to injunctive relief, ${ }^{8}$ circumscribed the geographic reach of infringement liability, ${ }^{9}$ questioned the range of patentable subject matter, ${ }^{10}$ and expanded the scope of both the exhaustion doctrine ${ }^{11}$ and the statutory experimental-use defense. ${ }^{12}$ By arguably opening the federal courts to patent challenges by

3. U.S. CONST. art. III; Declaratory Judgment Act, 28 U.S.C. $\S 2201$ (a) (2006).

4. See Sprint Commc'ns Co. v. APCC Servs., Inc., 128 S. Ct. 2531 (2008); MedImmune, 549 U.S. at 126-27, 137 n.11 (discussing Aetna Life Ins. Co. v. Haworth, 300 U.S. 227 (1937)); see also Teva Pharm. USA, Inc. v. Novartis Pharm. Corp., 482 F.3d 1330, 1346-47 (Fed. Cir. 2007) (Friedman, J., concurring).

5. The MedImmune Court specifically mentioned Cardinal Chem. Co. v. Morton Int'l, Inc., 508 U.S. 83 (1993), which held that a decision of noninfringement, even if it resolves a case, nonetheless does not moot a declaratory judgment counterclaim of patent invalidity. See MedImmune, 549 U.S. at 133 n.11.

6. See, e.g., Westinghouse Elec. \& Mfg. Co. v. Formica Insulation Co., 266 U.S. 342, 351 (1924).

7. KSR Int'l Co. v. Teleflex Inc., 550 U.S. 398 (2007).

8. eBay Inc. v. MercExchange, L.L.C., 547 U.S. 388 (2006).

9. Microsoft Corp. v. AT\&T Corp., 550 U.S. 437 (2007).

10. Lab. Corp. of Am. Holdings v. Metabolite Labs., Inc., 370 F. $3 d 1354$ (Fed. Cir. 2004), cert. denied, 548 U.S. 124 (2006) (Breyer, J., dissenting).

11. Quanta Computer, Inc. v. LG Elecs., Inc., 128 S. Ct. 2109 (2008).

12. Merck KGaA v. Integra Lifesciences I, Ltd., 545 U.S. 193 (2005). To be sure, patentees have also won a few cases: in Festo Corp. v. Shoketsu Kinzoku Kogyo Kabushi$k i$ Co., 535 U.S. 722 (2002), the Supreme Court reversed the Federal Circuit's constrained view of the doctrine of equivalents, and in Illinois Tool Works Inc. v. Indepen- 
licensees - indeed, by anyone with a substantial investment in the technology covered by the patent ${ }^{13}-$ MedImmune appears to create new avenues for courts to police the implementation of patent law and to release advances that should not have been patented into the public domain. As such, it extends the rationale of Lear v. Adkins, ${ }^{14}$ a forty-year-old case in which the Supreme Court rejected the contract-law doctrine of licensee estoppel and allowed a licensee that had repudiated its agreement to challenge the patent. According to the Lear Court:

Licensees may often be the only individuals with enough economic incentive to challenge the patentability of an inventor's discovery. If they are muzzled, the public may continually be required to pay tribute to would-be monopolists without need or justification. We think it plain that the technical requirements of contract doctrine must give way before the demands of the public interest .... ${ }^{15}$

Still, the MedImmune decision is, in significant ways, astonishing. As Sean O'Connor pointed out, the reasoning is ahistorical, convoluted, and blind to the realities of licensing practice. ${ }^{16}$ It effects a dramatic change in the rules of the licensing game by substantially enhancing the bargaining position of the licensee to the detriment of the patent holder. The licensee can now seek a new arrangement any time it can mount a credible contract dispute. Furthermore, it can do so without taking any real risk, for if the patent is upheld, the licensee can continue to rely on the license. At the same time, the patent holder is trapped in a difficult situation. It is tied to a deal that is unraveling and encumbered with substantial risk: because the Supreme Court also abolished the doctrine of mutuality of estoppel, ${ }^{17}$ any

dent Ink, Inc., 547 U.S. 28 (2006), the Court made it more difficult to prove that the patentee engaged in illegal tying.

13. See, e.g., SanDisk Corp. v. STMicroelectronics, Inc., 480 F.3d 1372 (Fed. Cir. 2007) (holding that conduct related to utilization of the patented invention can create a justiciable controversy, even when the patent holder denies a plan to sue). The Federal Circuit may, however, be retreating from this broad view. See Janssen Pharmaceutica, N.V. v. Apotex, Inc., 540 F.3d 1353, 1362-63 (Fed. Cir. 2008) (requiring more than speculative fear of harm to establish that the dispute is "definite and concrete"); Prasco, L.L.C. v. Medicis Pharm. Corp., 537 F.3d 1329 (Fed. Cir. 2008) (requiring the plaintiff to show an affirmative act by the patentee that demonstrates an intent to sue).

14. Lear, Inc. v. Adkins, 395 U.S. 653 (1969).

15. Id. at $670-71$.

16. Sean M. O'Connor, Using Stock and Stock Options to Minimize Patent Royalty Payment Risks After MedImmune v. Genentech, 3 N.Y.U. J. L. \& BuS. 381, 389-422, 429-34, 443-51 (2007).

17. Blonder-Tongue Labs., Inc. v. Univ. of Ill. Found., 402 U.S. 313 (1971). 
decision on patent invalidity will be good not only against the challenger, but also against the world.

Strangely, although the MedImmune decision is understood as part of the patent-law canon, there is virtually nothing in the opinion that rationalizes the result in terms of innovation policy. ${ }^{18}$ Indeed, if the decision is taken at face value, it would be hard to articulate a strong justification for the ways in which it changes licensing practice. ${ }^{19}$ True, it appears that the public will benefit from MedImmune because the decision effectively anoints a new group of "private attorneys general" with freedom to patrol the patent landscape and invalidate patents. But the asymmetries in the parties' bargaining positions will ultimately endanger the public interest in scientific progress. At the time of a challenge, the risk that the patent will be invalidated could lead the patent holder to settle on highly unfavorable terms. In such cases, the patent will remain in force. Accordingly, society will not gain free access to the invention. The patent holder will, however, lose revenue, leading to an impairment of patent value and a decrease in incentives to invent.

Furthermore, as John Schlicher has argued, ${ }^{20}$ as patent holders begin to understand the decision, they will raise licensing fees to compensate for assuming a new risk, or, as O'Connor has suggested, they will require licensees to pay the full cost of the license upfront. ${ }^{21}$ In either event, fewer deals will likely be made and fewer inventions will be put to sociallybeneficial uses. ${ }^{22}$ Worrisomely, these effects will be magnified in the emerging sectors (such as bioinformatics) that are the most critical to technological progress. In these areas, the value of the invention is often difficult to calculate, making running royalties the only efficient way to allocate benefits. At the same time, however, patentability law tends to be so highly unsettled that it is easy to mount credible challenges. To make

18. Interestingly, patent policy was extensively briefed by the parties and their amici. See Erik Belt \& Keith Toms, The Price of Admission: Licensee Challenges to Patents After MedImmune v. Genentech, 51-JUN. BosTON B.J. 10, 10, 12 (2007).

19. MedImmune has some implications with important public benefits. See infra notes 43-53 and accompanying text.

20. John W. Schlicher, Patent Licensing, What to Do After MedImmune v. Genentech, 89 J. PAT. \& TRADEMARK OFF. SOC'Y 368 (2007).

21. O'Connor, supra note 16, at 452-55; see also William H. Hollander, Challenging Patents Becomes Easier, 54-APR. FED. LAw. 18, 19 (2007).

22. See Stephanie Chu, Operation Restoration: How Can Patent Holders Protect Themselves From MedImmune?, 2007 DuKE L. \& TECH. L. REV. 0008, १ๆ 28-33; Jeffrey M. Butler \& Ashton J. Delauney, The Implications of MedImmune v. Genentech, INTELL. ASSET MGMT. (IAM) MAGAZINE, Feb. 2007 (Supplement), at 37, http://www.iammagazine.com/issues/article.ashx?g=5206255c-cbee-4de8-8426-9ea0d951a3c9. 
matters even worse, the participants are likely to be in poor positions to deal with either risk or cash-flow problems: the patent holders in emerging sectors are likely to be small companies that are highly dependent on their patent revenues, or universities, which rely on licensing income to fund their technology transfer operations. Meanwhile, the licensees could be cash-starved startups that cannot afford to pay for the license until their marketing efforts pay off.

Nor is it clear how legally-sophisticated and financially-well-endowed firms should deal with the problems generated by MedImmune, for the decision leaves many important issues hanging. Although the opinion appears to extend Lear, the Court twice noted that it was leaving various aspects of the licensee estoppel doctrine open. ${ }^{23}$ In addition, the Court insisted that its analysis was unaffected by whether the "case" it considered justiciable was a patent dispute (over validity and infringement) or a contract dispute (over whether royalties were owed under the license). ${ }^{24}$ Yet the Court supplied a rationale for finding the controversy justiciable only on the basis of the contract dispute - and then proceeded to leave the exact nature of that dispute murky. ${ }^{25}$ The opinion says the contested issue was whether the contract provided for the payment of royalties even if the patent was invalidated. ${ }^{26}$ But it is difficult to understand how that could be a litigable issue. As between the parties, the contract settled the question by explicitly providing that royalties were owed only on patents "which have neither expired nor been invalidated." ${ }^{27}$ Besides, existing case law holds that it is misuse to demand royalties that extend beyond the life of the patent. ${ }^{28}$ Even if it were plausible to interpret the contract as requiring postinvalidation payments, there would be a problem. Lear abrogated the doctrine of licensee estoppel in order to encourage validity challenges. But if, on remand, the trial court were to agree that payment was owed irrespec-

23. MedImmune, Inc. v. Genentech, Inc., 549 U.S. 118, 124 (2007) ("We express no opinion on whether a nonrepudiating licensee is similarly relieved of its contract obligation during a successful challenge to a patent's validity - that is, on the applicability of licensee estoppel under these circumstances."). Id. at 128 ("Assuming (without deciding) that respondents here could not claim an anticipatory breach and repudiate the license, the continuation of royalty payments makes what would otherwise be an imminent threat at least remote, if not nonexistent.").

24. Id. at 123 .

25. Id. at 123; see also id. at 140 ("[T]he Court never explains what the supposed contract dispute is actually about.") (Thomas, J., dissenting).

26. See, e.g., MedImmune, Inc. v. Genentech, Inc., 549 U.S. 118, 125 (2007).

27. See infra note 36 and accompanying text.

28. See Brulotte v. Thys Co., 379 U.S. 29, 32 (1964). 
tive of whether the patent was valid, it would never reach the validity issue, and the goal of Lear would be frustrated. ${ }^{29}$

In fact, the best reading of MedImmune is that it reverses Lear or, more accurately, the received wisdom on what Lear means. Thus, while Lear is understood as prohibiting the enforcement of any contract provision that reduces the licensee's incentive to challenge validity, ${ }^{30} \mathrm{MedIm}$ mune can be interpreted as permitting patent holders to bargain for such restrictions. The Court's analysis of the contract issue suggests that patent holders could avoid challenge by nonrepudiating licensees by simply omitting reference to the validity of the licensed patent. ${ }^{31}$ Moreover, by specifically noting that "it is not clear where [in the contract] the prohibition against challenging the validity of patents is found,"32 the Court implied that if it had found a no-contest provision, it would have enforced it.

Although this interpretation of MedImmune is counterintuitive in that it permits licensees to be "remuzzled," it does so only when the licensee has notice that its opportunity to challenge the patent is truncated. Not only does this interpretation have the salutary effect of spurring the licensee to fully vet the patent before it is licensed, it also comports rather well with many of the jurisprudential developments that have occurred since Lear was decided-with modern economic theory about the monopolizing potential of patents and the problems of risk allocation, with increased appreciation for the need to promote technology transfer, as well as with current views on the interface between federal intellectual property law and

29. MedImmune, 549 U.S. at 124 n.3. The resolution of the case also raises a difficult issue concerning subject matter jurisdiction. The Declaratory Judgment Act does not confer subject matter jurisdiction; its sole function is to change the time when a suit can be brought. Thus, the basis for jurisdiction must be found in other law. Genentech is a California corporation and MedImmune is located in Maryland; accordingly, there was diversity jurisdiction in the actual case. See 28 U.S.C. $\S 1332$ (2006). Had the parties both been domiciled in the same state, the only possible bases for jurisdiction would be federal question jurisdiction, 28 U.S.C. $\S 1331$ (2006), or patent jurisdiction, 28 U.S.C. $\S 1338$ (2006). But if the dispute was justiciable because of a contract issue, it is not clear that the federal issue would have been prominent enough to put the case on the federal docket. See, e.g., Merrell Dow Pharm. Inc. v. Thompson, 478 U.S. 804 (1986); Franchise Tax Bd. of Cal. v. Constr. Laborers Vacation Trust for So. Cal., 463 U.S. 1 (1983). But see Grable \& Sons Metal Prods., Inc. v. Darue Eng'g \& Mfg., 545 U.S. 308 (2005) (taking an interest-based approach to the issue of federal question jurisdiction).

30. See Rochelle Cooper Dreyfuss, Dethroning Lear: Licensee Estoppel and the Incentive to Innovate, 72 VA. L. REV. 677, 694-95 (1986) (citing post-Lear cases); see also Pope Mfg. Co. v. Gormully, 144 U.S. 224 (1892) (refusing to enforce a licensee's promise not to contest the validity of the licensed patent).

31. See Schlicher, supra note 20, at 367.

32. MedImmune, 549 U.S. at 135. 
state contract law. ${ }^{33}$ Policing the patent landscape remains an important objective, but as one of us pointed out over twenty years ago, relaxing the requirements for declaratory judgment relief and reforming procedures within the Patent and Trademark Office ("PTO") provide effective avenues for testing patent validity without interfering with the bargains that are crucial to the dissemination of knowledge. ${ }^{34}$

Part II of this Article examines the consequences of MedImmune and sets out the arguments for reading it as promoting private ordering, even when the arrangements impair the propensity of licensees to bring validity challenges. Part III makes the arguments about the vitality of Lear and its lore more concrete by discussing five general approaches to contracting in light of MedImmune, each representing a different view of MedImmune's effect on prior case law. The Article concludes that MedImmune is best read as giving parties considerable freedom to tailor relationships to meet business needs. This freedom is, however, based on the notion that party autonomy usually serves an important public purpose. But the public interest is not always served by private arrangements. For example, in opening the door to more patent challenges, MedImmune suggests that the public interest in settling disputes does not outweigh other social goals. Thus, the decision casts doubt on a line of cases upholding agreements between branded pharmaceutical companies and generic manufacturers which eliminate competition in the name of reducing litigation costs. ${ }^{35}$

33. See infra notes 74-82 and accompanying text.

34. 35 U.S.C. $\S \S 311-312$ (2006) (ex parte reexamination); 35 U.S.C. $\S \S 313-316$ (2006) (inter partes reexamination); Dreyfuss, supra note 30, at 756-64 (discussing declaratory relief and reexamination). Congress also contemplated the institution of a postgrant opposition procedure which would significantly expand the scope of inter partes validity challenges in the PTO from that available via inter partes reexamination. See Patents Depend on Quality Act of 2006, H.R. 5096, 109th Cong. (2006); H.R. 5418, 109th Cong. (2006); Patent Reform Act of 2005, H.R. 2795, 109th Cong. (2005); see also John E. Calfee \& Claude Barfield, Congress's Patent Mistakes, Wall ST. J., Oct. 29, 2007 , at A18 (suggesting that the opposition procedure is one of the few "useful and innovative" reforms in the bills).

35. See, e.g., In re Tamoxifen Citrate Antitrust Litig., 466 F.3d 187, 202 (2d Cir. 2006); Schering-Plough Corp. v. F.T.C., 402 F.3d 1056, 1068 (11th Cir. 2005); Valley Drug Co. v. Geneva Pharm., Inc., 344 F.3d 1294, 1304 (11th Cir. 2003) (rejecting antitrust challenges to settlement agreements); see also S. 369, 111 th Cong. (2009) (proposing to ban brand name pharmaceutical firms from making reverse-payment settlements in order to keep generics off the market). 


\section{MEDIMMUNE AND ITS RAMIFICATIONS FOR LAW, LORE, AND LICENSING}

\section{A. The Case}

Both of the parties in MedImmune operate in the biotechnology sector: Genentech, one of the founders of the field, generates upstream genetic information, which it uses and licenses to others for the purpose of finding new biotherapeutic products; MedImmune develops medicines to treat a variety of diseases. The parties' 1997 agreement involved two sets of advances, one covered by a patent that had issued prior to the license; the other was, at the time of the negotiations, the subject of a pending patent application. MedImmune agreed to pay royalties on all "licensed products," defined to include:

[any product] the manufacture, use or sale of which ... would, if not licensed under th[e] Agreement, infringe one or more claims of either or both of [the covered patents,] which have neither expired nor been invalidated by a court or other body of competent jurisdiction from which no appeal had been or may be taken. ${ }^{36}$

The license agreement gave MedImmune the right to terminate on six months' notice.

At the outset of the relationship, MedImmune did not utilize any of Genenetech's technology. However, four years into the agreement, a patent was awarded on the pending application. Genentech immediately sent MedImmune a letter expressing its belief that the new patent covered Synagis, a drug that prevented respiratory tract disease in infants and young children and which accounted for $80 \%$ of MedImmune's revenue. Although MedImmune thought the patent was invalid, unenforceable, and not infringed, it regarded the letter as a threat to terminate the license and sue for infringement. Fearing monetary liability (including treble damages and attorneys' fees) and loss of the bulk of its business, MedImmune paid "under protest and with reservation of all of [its] rights." ${ }^{37}$ It then brought a declaratory judgment action to clarify its position. At the time, Federal Circuit case law required a declaratory plaintiff to establish a controversy by showing that it had a basis for fearing an imminent suit by the patentee and by demonstrating activity that constituted infringement or the intent to infringe. ${ }^{38}$ Since MedImmune was a licensee in good standing, the district court reasoned that it was not in apprehension of a suit. Accordingly, the

36. MedImmune, 549 U.S. at 121.

37. Id. at 122 .

38. See, e.g., Gen-Probe Inc. v. Vysis, Inc., 359 F.3d 1376, 1379 (Fed. Cir. 2004). 
court dismissed the claims on subject matter jurisdiction-in fact, justiciability_grounds; the Federal Circuit affirmed. ${ }^{39}$

The Supreme Court reversed. Justice Scalia spent the first part of the opinion bringing patent law into line with justiciability doctrine in other fields. He began by rehearsing the Court's test for justiciability - that the "dispute be 'definite and concrete, touching the legal relations of parties having adverse legal interests'; and that it be 'real and substantial' and 'admi[t] of specific relief.' "40 $\mathrm{He}$ ended, in a footnote, by rejecting the Federal Circuit's apprehension-of-suit requirement. ${ }^{41}$ In the main part of the opinion, the Court examined the circumstances to determine whether MedImmune's continuing royalty payments meant that the dispute was not justiciable. It reasoned that if MedImmune were required to repudiate the agreement in order to put the validity and infringement of the patent into issue, it would, in effect, be put to a choice-risk its business or abandon its rights. Since the precise goal of the Declaratory Judgment Act is to relieve the plaintiff of the obligation to "bet the farm," even without repudiation, there was a "case of actual controversy" within the meaning of the Act and a "case" or "controversy" within the meaning of the Constitution.

In many ways, MedImmune is a welcome decision. If there were general confidence in patent law doctrine and in the workings of the PTO, the Federal Circuit's apprehension-of-suit requirement would supply an important limit on the availability of declaratory relief. Erecting a high barrier to suit protects patent value because it prevents those with an interest in the field of the invention from wearing down the patent holder with successive-and expensive-lawsuits. In the licensing context, a high barrier equalizes the risks of the licensee and the patent holder: the patent holder's risk of having the patent invalidated against the world is balanced by the requirement that the licensee repudiate the contract and risk the possibility that it will no longer enjoy the right to practice the patented invention. In the MedImmune Court's words, both sides must bet the farm. The result promotes settlement (or, better, respect for the agreement).

However, the current climate is one in which patents are regarded with considerable suspicion. Observers question the capacity of the PTO to conduct adequate examinations and thus view litigation as an important

39. MedImmune, 549 U.S. at 122.

40. Id. at 126-127 (citing Aetna Life Ins. Co. v. Haworth, 300 U.S. 227, 240-41 (1937)).

41. Id. at 132 n. 11 .

42. Id. at 129 . 
avenue for testing validity. ${ }^{43}$ As noted earlier, the Supreme Court has also evinced doubts about the law the PTO is required to apply. ${ }^{44}$ In that situation, the Federal Circuit's apprehension-of-suit test works a great deal of mischief. Suspecting that their patents may be invalid, patent holders are reluctant to actually permit them to be challenged in court. Nonetheless, the high barrier to suit allows these patents to be used to chill competition. Patent holders can send potential users ambiguous messages"discussions" of their patent positions-that interfere with customer relationships and discourage investment in the infrastructure necessary to practice or market the invention. ${ }^{45}$ As long as these "discussions" fall short of explicit threats to sue, the apprehension-of-suit test prevents recipients from going to court to clear their positions. Even if the patent holder allows a case to go to trial, it can have souring litigation dismissed prior to judgment by simply interposing a promise not to assert claims related to existing activity.

National health policy is also endangered. The Hatch-Waxman $\mathrm{Act}^{47}$ promotes competition in the pharmaceutical sector by giving a generic producer the right to apply for clearance to market a patented drug during

43. See generally, AdAM B. JAFFE \& JOSH LERNER, INNOVATION AND ITS DiSCONTENTS (2004); Mark A. Lemley, Rational Ignorance at the Patent Office, 95 Nw. U. L. REV. 1495 (2001).

44. See supra notes 7-10 and accompanying text; see also Rochelle Cooper Dreyfuss, In Search of Institutional Identity: The Federal Circuit Comes of Age, 23 BERKELEY TECH. L.J. 787, 791 (2008) ("[B]ecause the Supreme Court has either reversed or vacated virtually all the Federal Circuit patent decisions that it has recently reviewed, 'dissatisfied' may be a more accurate description of its attitude.").

45. For an example of this type of activity, see the facts of SanDisk Corp. v. STMicroelectronics NV, 480 F.3d 1372, 1374-76 (Fed. Cir. 2007). Cf. Arrowhead Indus. Water, Inc. v. Ecolochem, Inc., 846 F.2d 731, 735 (Fed. Cir. 1988) (noting that without the possibility of declaratory relief, competitors were "victimized" by patent owners who engaged in "extra-judicial patent enforcement with scare-the-customer-and-run tactics that infect[ed] the competitive environment of the business community with uncertainty and insecurity.").

46. For an example of this type of activity, see the facts of Benitec Austl., Ltd. v. Nucleonics, Inc., 495 F.3d 1340, 1342-43 (Fed. Cir. 2007). See also Caraco Pharm. Labs., Ltd. v. Forest Labs., Inc., 527 F.3d 1278 (Fed. Cir. 2008). Also of interest is the family of consolidated cases involving Columbia University's Richard Axel patent. After Judge Wolf commented unfavorably on the validity of the patent in Biogen Idec MA Inc. v. Trustees of Columbia University, 332 F. Supp. 2d 286, 297 (D. Mass. 2004), Columbia sought to end the litigation by granting covenants not to sue. See In re Columbia Univ. Patent Litig., 343 F. Supp. 2d 35 (D. Mass. 2004).

47. Drug Price Competition and Patent Term Restoration ("Hatch-Waxman") Act of 1984, Pub. L. No. 98-417, 98 Stat. 1585 (2006) (including scattered amendments to titles $15,21,28$, and 35 of the United States Code). 
the patent period. The Act also allows a proprietary manufacturer to treat such an application as patent infringement and sue to keep the generic off the market. ${ }^{48}$ However, because of the requirements of the apprehensionof-suit test, rather than permit a court to test the validity of its entire patent position relative to the drug in question, a proprietary manufacturer can sue on only a few of the relevant patents. Without the ability to bring a declaratory judgment action to deal with the other patents, the generic is left without the assurance it needs to launch its (much cheaper) products. ${ }^{49}$

Under MedImmune, however, these tactics are less likely to be successful. Several cases have reached the Federal Circuit in the aftermath of MedImmune. In each case in which the court thought this form of gamesmanship was going on, it permitted the litigation to go to judgment. ${ }^{50}$ At the same time, however, the court has been able to protect patent holders from abusive practices. It has relied on the standard justiciability requirements of concreteness, adversariness, and redressability to limit the range of potential declaratory plaintiffs to those who have made a substantial investment in the patented technology. ${ }^{51}$ In addition, the court has stressed that the Declaratory Judgment Act gives trial courts discretion to dismiss cases even when they are justiciable. That discretion, the court has suggested, is properly exercised in situations where the declaratory plaintiff is behaving opportunistically. ${ }^{52}$ The court has also noted that patent holders

48. 21 U.S.C. $\S 355$ (2006); 35 U.S.C. $§ 271(e)$ (2006); see 21 U.S.C. § 355(j)(5)(C) (creating a "[c]ivil action to obtain patent certainty").

49. See, e.g., Caraco, 527 F.3d at 1296-1297; Teva Pharm. USA, Inc. v. Novartis Pharm. Corp., 482 F.3d 1330, 1243 (Fed. Cir. 2007).

50. See Caraco, 527 F.3d at 1297; Teva, 482 F.3d at 1346; SanDisk, 480 F.3d at 1383. But see Prasco LLC v. Medicis Pharm. Corp., 537 F.3d 1329, 1341 (Fed. Cir. 2008) (requiring that the plaintiff show an affirmative act by the patentee demonstrating an intent to sue). Cf. Benitec, 495 F.3d at 1351 (Dyk J., dissenting from a dismissal of a declaratory judgment action on the ground that "patentee's manipulative efforts to defeat declaratory jurisdiction are clear enough").

51. See Cat Tech L.L.C. v. TubeMaster, Inc., 528 F.3d 871, 880 (Fed. Cir. 2008) (noting that until the declaratory plaintiff has taken substantial steps toward utilizing the patent, the facts are too fluid to entertain an action); see also Benitec, 495 F.3d at 1346 (describing that when research protected by the research exemption, 35 U.S.C. $\S$ 271(e)(1) (2006), is underway, the suit is not ripe); cf. Janssen Pharmaceutica, N.V. v. Apotex, Inc., 540 F.3d 1353, 1360-61 (Fed. Cir. 2008) (requiring the declaratory plaintiff to demonstrate that the alleged harm was caused by the dispute over the validity of the patent in issue); Adenta GmbH v. OrthoArm, Inc., 501 F.3d 1364, 1369-70 (Fed. Cir. 2007) (verifying that the relationship between the parties was adversarial).

52. See, e.g., Sony Elecs., Inc. v. Guardian Media Techs., Ltd., 497 F.3d 1271, 1289 (Fed. Cir. 2007) (suggesting that if the facts supported the contention that there was "a strategic motive to obtain a more favorable bargaining position in the ongoing negotiations with the patentee and also to undermine the value of the patent so as to impede its 
can sometimes protect themselves from a multiplicity of suits by using the transfer provisions of federal law to consolidate all related cases before a single tribunal. ${ }^{53}$

\section{B. Ramifications for Licensing}

Despite these advantages for the administration of patent law generally, MedImmune raises substantial concerns in the licensing context. As explained in the Introduction, the holding substantially alters the parties' bargaining position. In its effort to save the licensee from having to "bet the farm," the Court shifted the entire litigation risk to the patent holder. Because of Blonder-Tongue and the demise of mutuality of estoppel, ${ }^{54}$ a declaration of patent invalidity is good against the world, and not just against the challenger. Accordingly, an adverse decision will destroy the entire income stream flowing from the patent. Knowing the risk, patent holders are much more likely to settle improvidently. As a result, the patent will remain in force, but the licensee will now capture part of the supracompetitive return associated with it. Since patents are rarely vulnerable on the ground that the licensee was the true inventor, payments wind up going to the wrong party and incentives to innovate are weakened.

It is not even clear that pre-litigation settlements with licensees will stick, for the question whether settlements should be treated like consent decrees-which are presumably entitled to res judicata effect ${ }^{55}$-or like any other contract has long been controversial. ${ }^{56}$ The rationale for barring the settling licensee from attacking the patent is that the public interest in avoiding litigation is strong enough to overcome Lear's goal of opening the courthouse door to validity challenges. But since the MedImmune Court surely knew that its decision was bound to produce considerable

sale or licensing to a third party," the trial court could dismiss the case; no such motive was, however, shown); see also Cellco P'ship v. Broadcom Corp., No. 2006-1514, 2007 WL 841615, at*1 (Fed. Cir. Mar 19, 2007) (suggesting that a court could exercise its discretion to dismiss a case when multiple related actions are pending).

53. Micron Tech., Inc. v. Mosaid Techs., Inc., 518 F.3d 897, 903-905 (Fed. Cir. 2008) (explaining that "the possibility of consolidation with related litigation" qualifies as a factor courts must consider when weighing transfer between forums under 28 U.S.C. $\S 1404(a))$.

54. Blonder-Tongue Labs., Inc. v. Univ. of Ill. Found., 402 U.S. 313, 333 (1971).

55. See, e.g., Interdynamics, Inc. v. Firma Wolf, 653 F.2d 93, 96-97 (3d Cir. 1981); Am. Equip. Corp. v. Wikomi Mfg. Co., 630 F.2d 544, 546 (7th Cir. 1980) (explaining that although a consent decree may in rare cases be denied res judicata effect for overriding public policy reasons, such decrees are generally held to bar a party from subsequently relitigating the issues settled by the decree); Schlegel Mfg. Co. v. USM Corp., 525 F.2d 775, 781 (6th Cir. 1975).

56. Dreyfuss, supra note 30 , at 720 ; see also infra note 115 and accompanying text. 
litigation, it may be that the Court no longer values litigation avoidance as highly as it does patent invalidation. Accordingly, there may be little to be gained from settling without the imprimatur of a consent decree.

The patent holder will also likely suffer during the time the case is being litigated. Post-MedImmune, there has been considerable debate among practitioners on whether a licensee can recover royalties paid during the time that a case is pending. Some practitioners have suggested that royalties be paid into an escrow account, from which they can be recovered should the patent prove invalid or not infringed. ${ }^{57}$ If this is possible, then patent holders will not even be able to use profits from the patent to fund the litigation. Furthermore, as $\mathrm{O}^{\prime}$ Connor points out, ${ }^{58}$ if the license is exclusive, then the patent holder will not have the right to negotiate with others. If the license is not exclusive, then in theory, new licensing partners could be found. In practice, however, it is not likely anyone will take-and abide by-a license to a patent that is undergoing challenge.

Of course, the patent holder can charge the licensee more to offset these risks. But that would raise the cost of the products produced under the license and reduce the potential pool of licensees, possibly leading to underutilization of the patented invention. ${ }^{59}$ The patent holder could also try to avoid licensee challenges by demanding full payment upfront. However as explained further below, there is a significant downside to that approach. Especially in situations where substantial development of the invention is required before it can be marketed, potential licensees may be unwilling to devote their available funds to paying off licensing fees. Licensees who are just starting out may not even have the money to make the payment. Furthermore, at the time of the negotiation, before the risky business of development and commercialization has been completed suc-

57. It has also been suggested that in the future, licensees should bargain for the right to have royalty fees held in escrow during a patent challenge. See, e.g., Mark Henry, Patent Licensing After MedImmune v. Genentech, INTELL. PrOP. TODAY, Apr. 2007, at 22, http://www.iptoday.com/pdf/2007/4/Henry-Apr2007.pdf; Michael J. Cavaretta \& Howard G. Zaharoff, Patent Licensing Strategies After MedImmune v. Genentech, IP News (Morse, Barnes-Brown \& Pendleton, P.C., Waltham, Mass.), May 2008, http://www.mbbp.com/resources/iptech/newsletters/pdfs/ip0508.pdf; Cooley Alert!, MedImmune v. Genentech: A Dilemma Removed for Patent Licensees, COOLEY ALERT! (Cooley Godward Kronish L.L.P., Palo Alto, Cal.), Feb. 15, 2007, http:// www.cooley.com/files/tbl_s24News\%5CPDFUpload 152\%5C2554\%5CALERT_MedIm muneVGenentech.pdf; Frank X. Curci et al., Intellectual Property Client Alert: Adapting Your Licensing Strategy to Recent Patent Law Changes, CLIENT ALERT (Jennings Strouss, and Salmon, P.L.C., Phoenix, Ariz.), June 2008, http://www.jsslaw.com/ uploads/publication/Patent \%20Licensing\%20\%206-08\%20Client\%20Alert.pdf.

58. O'Connor, supra note 16 , at 447.

59. See generally Schlicher, supra note 20, at 389-93. 
cessfully, the parties may be unable to accurately determine the benefits that will flow from the invention. In contrast, a running royalty provision insures that the licensee will not have to pay if the invention turns out to be worthless. At the same time, it gives the patent holder the assurance of a fair return on a successful invention.

O'Connor has suggested that all of these problems could be solved by compensating the patent holder with a combination of stock and stock options designed to mirror the contribution that the invention makes to the licensee's business. But as he notes, not all patent holders are in a position to administer stock portfolios and comply with the requirements of securities laws; the relationship between the stock price and the performance of the invention may be extremely imperfect (especially if the licensee's business is diversified); and the stock distribution could have an adverse impact on the licensee's other investors. ${ }^{60}$ At best, then, this approach can only provide a partial solution to the MedImmune problem.

\section{Ramifications for Patent Law and Lore}

In some ways, it is difficult to understand why the Court left the licensing situation in so much disarray: why Justice Scalia implied, by noting that a promise to pay is not the same as a promise not to challenge, that if there had been a promise not to challenge in the licensing agreement, it would have been enforced; ${ }^{61}$ why he thought that there was a genuine contractual dispute concerning the temporal scope of MedImmune's obligation to pay royalties; ${ }^{62}$ or why he suggested that there were various aspects of the doctrine of licensee estoppel that MedImmune was leaving open. ${ }^{63}$ After all, each of these issues appears to have been well settled by three 1960's-era cases. Brulotte v. Thys Co. ${ }^{64}$ and Zenith Radio Corp. v. Hazeltine Research, Inc. ${ }^{65}$ which deemed it misuse to stretch payments beyond the time when the patent was in force or to require payment on account of products that do not use the teachings of the patent, are understood as preventing the patent holder from extracting running royalties for anything other than utilization of a valid patent. And the aforementioned Lear, which abrogated the common law doctrine of licensee estoppel, is

60. See O'Connor, supra note 16, at 451-72.

61. MedImmune, Inc. v. Genentech, Inc., 549 U.S. 118, 123, 135 (2007).

62. Id. at $123-24$.

63. Id. at $124,128$.

64. Brulotte v. Thys Co., 379 U.S. 29 (1964).

65. Zenith Radio Corp. v. Hazeltine Research, Inc., 395 U.S. 100, 135 (1969). 
read as foreclosing the use of no-contest clauses or, indeed, other disincentives to licensee challenges. ${ }^{66}$

In fact, Lear appeared to directly address the patent law question at issue in MedImmune. It treated the problem of a repudiating licensee as a harder question than that of the nonrepudiating licensee. That is, the Lear Court started from the assumption that licensees should not be permitted to withhold royalties before the patent was invalidated, but came to the conclusion that it would tolerate breach because the prospect of saving money would induce more licensees to mount challenges. ${ }^{67}$

It is, of course, conceivable that the MedImmune Court simply failed to understand the lore associated with these cases. ${ }^{68}$ But because the Court raised the issue and then made no effort to explain the policy underlying its decision to unmuzzle nonrepudiating licensees, a strong argument can be made that it meant to suggest that licensees need not remain unmuzzled. $^{69}$ That is, perhaps the Justices focused narrowly on the procedural issue of what constituted a case or controversy (which, in fact, was never addressed in Lear) because they wanted to leave the lore (if not the holdings) of these earlier cases open for reconsideration.

Lear did not, after all, deal with contractual provisions that bar challenges. Although it used broad language that allowed courts and practitioners to believe that provisions barring licensees from challenging patents would be unenforceable, the decision dealt only with the clash between a background rule - the contract-law doctrine of licensee estoppeland federal patent policy. ${ }^{70}$ In a sense, the decision was another manifesta-

66. Lear, 395 U.S. 653, 673 (1969); see also Pope Mfg. Co. v. Gormully, 144 U.S. 224 (1892) (refusing to enforce a licensee's promise not to contest the validity of the licensed patent).

67. Lear, 395 U.S. at 673. Indeed, at one point during oral arguments in MedImmune, Justice Scalia interjected: "Gee, there's less here than meets the eye." Transcript of Oral Argument at 22, MedImmune v. Genentech, 549 U.S. 118 (2007) (No. 05-608).

68. Certainly, the oral argument was replete with questions that the patent bar has long regarded as decided. See Transcript of Oral Argument, supra note 67, at 4, 5, 17, 20, $21,28$.

69. See, e.g., MedImmune, Inc. v. Genentech, Inc., 549 U.S. 118, 124 (2007) ("We express no opinion on whether a nonrepudiating licensee is similarly relieved of its contract obligation during a successful challenge to a patent's validity ....") (emphasis in original).

70. Pope, 144 U.S. at 244. Pope, which is also cited for the proposition that nocontest clauses are impermissible, also admits of a narrower interpretation. First, the question presented was whether a court of equity could enforce the contract. Id. at 236. Second, the contract did much more than bar the licensee from challenging the licensed patent: among other things, it gave the patent holder the right to control the retail price, it barred the licensee from selling products that competed with the licensed patented inven- 
tion of a trope running through a series of contemporaneous Supreme Court cases on the appropriate relationship between federal patent law and state contract law. ${ }^{71}$ Brulotte and Zenith emanated from a similar concern: in both cases, the Court feared that patent holders would utilize contracts to leverage rights under the patent into broader control over the market. ${ }^{72}$

In the new millennium, much of this thinking has changed. The " $60 \mathrm{~s}$ Court had a highly stylized view of the interface between federal and state law: its notion was that anything that was not patented or copyrighted was necessarily in the public domain. ${ }^{73}$ But that idea has given way to a much more nuanced appreciation for the benefits of private ordering and for the important role that contracts play in transferring technology and in encouraging creative production outside the formal intellectual property system. ${ }^{74}$ Although the Court still occasionally finds a state law that is preempted by federal innovation law and policy, ${ }^{75}$ over the forty-odd years since the early cases were decided, the federal/state interface has been substantially refigured. Subsequent to Lear, Brulotte, and Zenith, the Court upheld a contract, negotiated during the pendency of a patent application, which required the payment of royalties even if a patent never issued, ${ }^{76}$ it permitted California to protect sound recordings before the Cop-

tion (bicycles), and prohibited the licensee from challenging other patents held by the licensor. The Court found the entire license unenforceable as against public policy because it was a restraint on trade. Id. at 233-34.

71. See, e.g., Lear, 395 U.S. at 668; Compco Corp. v. Day-Brite Lighting, Inc., 376 U.S. 234 (1964); Sears, Roebuck \& Co. v. Stiffel Co., 376 U.S. 225 (1964).

72. See, e.g., Zenith Radio Corp. v. Hazeltine Research, Inc., 395 U.S. 100, 135 (1969); Brulotte v. Thys Co., 379 U.S. 29, 33 (1964).

73. See supra note 71.

74. There is an extensive literature on the use of contracts to override elements of federal intellectual property law, particularly on the copyright side where the Creative Commons License and the General Public License enjoy considerable popularity. See, e.g., Daniel Laster, The Secret is Out: Patent Law Preempts Mass Market License Terms Barring Reverse Engineering for Interoperability Purposes, 58 BAYLOR L. REV. 621 (2006); Lydia Pallas Loren, Building a Reliable Semicommons of Creative Works: Enforcement of Creative Commons Licenses and Limited Abandonment of Copyright, 14 GEO. MASON L. REV. 271 (2007); Katherine M. Nolan-Stevaux, Open Source Biology: A Means to Address the Access and Research Gaps?, 23 SANTA ClARA COMPUTER \& HigH TECH. L.J. 271 (2007); Molly Shaffer Van Houweling, The New Servitudes, 96 GEO. L.J. 885 (2008).

75. See Feist Publ'ns, Inc. v. Rural Tel. Serv. Co., 499 U.S. 340, 364 (1991); Bonito Boats, Inc. v. Thunder Craft Boats, Inc., 489 U.S. 141, 152-54 (1989).

76. Aronson v. Quick Point Pencil Co., 440 U.S. 257, 266-67 (1979) (Blackmun, J., concurring) (questioning the vitality of Brulotte and concurring on the theory that it is important to permit "parties to structure their bargains efficiently"). 
yright Act covered them, ${ }^{77}$ and it approved the application of state trade secrecy law even in cases where the advance could have been patented. ${ }^{78}$ Because of these decisions, licensing parties now appear to enjoy considerably more freedom to structure their relationships in the manner that makes the most business sense, so long as their arrangement gives both sides notice of the restrictions imposed and so long as those restrictions yield social benefits. ${ }^{79}$

Equally important, because patents are no longer viewed as monopolies in the true economic sense, the Court has largely abandoned its concerns about leverage. Thus, antitrust and misuse cases from the ' $60 \mathrm{~s}$ that found certain practices to be per se violations of the law have largely been overruled in favor of an approach that requires proof that the patent confers market power. ${ }^{80}$ In this new environment, the result in Brulotte (and perhaps even Zenith) is highly questionable. Without knowing how much economic power the patent conferred, there is no way to determine whether the contractual promise to continue payments beyond the term of the patent was produced by leverage. In fact, if the Court were now confronted with a license like the one in Brulotte, it would likely start from the assumption that the licensee was paying no more for the invention than it was worth, that compensation was set to reflect the risk that that the patent might be invalidated before it expired, and that the total payout was simply spread over a longer period of time. ${ }^{81}$ If the Court needed an economic purpose for the arrangement, two are readily at hand: spreading the

77. Goldstein v. California, 412 U.S. 546, 575 (1973).

78. Kewanee Oil Co. v. Bicron Corp., 416 U.S. 470, 474 (1974). See generally Paul Goldstein, The Competitive Mandate: From Sears to Lear, 59 CALIF. L. REV. 873, 903 (1971).

79. For example, in Quanta Computer, Inc. v. LG Electronics, Inc., 128 S. Ct. 2109 (2008), the court extended the scope of patent exhaustion to process patents and refused to permit parties to a patent agreement to abrogate the patent exhaustion doctrine. In that case, however, the import of the agreement was unclear, producing strong negative externalities. Notably, the Quanta Court refrained from explicitly overruling decisions like Mallinckrodt, Inc. v. Medipart, Inc., 976 F.2d 700 (Fed. Cir 1992), where the contract was clear and the bar on reuse protected the quality (sterility) of the inhalers that were the subject of the patent. But see Static Control Components, Inc. v. Lexmark, Int'l, Inc., 2008 WL 1970241 (E.D. Ky., Mar. 31, 2009) (No. 5:02-571) (refusing to enforce a contract restriction on exhaustion grounds).

80. See, e.g., Ill. Tool Works Inc. v. Indep. Ink, Inc., 547 U.S. 28 (2006); Charles F. Rule, The Administration's Views: Antitrust Analysis After The Nine No-No's, 55 ANTITRUST L.J. 365 (1986).

81. William F. Baxter, Legal Restrictions on Exploitation of the Patent Monopoly: An Economic Analysis, 76 YALE L.J. 267, 327-29 (1966); Dreyfuss, supra note 30, at 707-12. 
payments across a broader time frame reduces the cost of marketing the invention and makes the invention more accessible. Furthermore, the arrangement is in the nature of a loan. It permits a cash-poor licensee to work the patent (for example, to use its teachings to develop new medicines) at lower cost than if the payout term were limited to the life of the patent. $^{82}$

Once it is recognized that patents do not necessarily command significant economic power, and that contractual agreements can serve the public, agreements that discourage (or bar) licensees from challenging the licensed patent look much less suspicious. They avoid the power asymmetry problems noted above and permit licensing by thinly capitalized entrepreneurs and in emerging sectors, such as biotechnology, where the benefits of patented inventions are difficult to evaluate. ${ }^{83}$ So long as potential licensees understand at the outset that they will not be allowed to challenge validity after they enter into the contract (that is, so long as the clause is in the contract-as Justice Scalia suggested ${ }^{84}$-rather than arising through a common law estoppel doctrine), they have every incentive to assess patent strength before committing to a license. If a potential licensee were to decide the patent was weak, it could negotiate for a lower payment term or it could simply infringe and wait to be sued. Alternatively, if it wanted to clear its position before investing, the procedural holding in MedImmune - if interpreted liberally - would allow it to raise the validity issue in a declaratory judgment action. Indeed, if the pending legislative proposal to institute an opposition proceeding is enacted, the licensee might be able to challenge the patent on the cheap, in the PTO rather than in court. ${ }^{85}$

This approach produces significant social benefits. Indeed, altering the timing of the licensee's propensity to sue arguably produces a better result than the one that obtains under Lear. The public acquires free use of the patented information sooner that it would if the licensee were permitted to wait and examine the patent at its leisure. Development and exploitation would then occur in a competitive environment, where they may result in

82. For these reasons, courts have begun to question the continuing vitality of Brulotte. See, e.g., Zila, Inc. v. Tinnell, 502 F.3d 1014 (9th Cir. 2007) (questioning, but applying, Brulotte); Scheiber v. Dolby Labs., Inc., 293 F.3d 1014 (7th Cir. 2002) (questioning, but applying, Brulotte).

83. See, e.g., Brief of the Biotechnology Indus. Org. as Amicus Curiae in Support of Neither Party, Quanta Computer, Inc. v. LG Elecs., Inc., 128 S. Ct. 2109 (2008) (No. 06937).

84. MedImmune, Inc. v. Genentech, Inc., 549 U.S. 118, 135 (2007).

85. See supra note 34 . 
more - or less - expensive products. In addition, the ability to enter an agreement that locks in royalties furthers the goals of the Bayh Dole Act. ${ }^{86}$ Another post-Lear development, Bayh-Dole gives universities the right to patent inventions arising out of federally-funded research in order to promote the transfer of fundamental research from academia into the private sector, where it can be used to solve real-world problems. ${ }^{87}$ Universities are, however, wary of diverting endowment and tuition funds from research and teaching. Because they instead rely on a steady income from licensing to identify promising academic projects, find appropriate private sector partners, and negotiate agreements, ${ }^{88}$ a rule that permits them to contract out of the uncertainties produced by MedImmune and Lear is particularly advantageous. ${ }^{89}$

Agreements that limit the licensee's freedom to engage in patent litigation also prevent licensees from gaming the system. Licensees cannot use the shelter of the patent to develop products, markets, trademark recognition, and a customer base, and then avoid the obligation to pay for the privileges they enjoyed. In fact, as one of us noted in an earlier article, while the Lear Court may have been right to be wary of the PTO, its confidence in licensees may have been largely misplaced:

As long as the patent is thought to be valid, the licensees and the patentee are the only parties with the legal right to practice the invention. The patent confers exclusivity; a successful challenge to it invites competition. Certainly, it is possible that an infringer will enter into competition with the licensee and, unhampered by royalties, undersell the licensee. In that event, the licensee may be inclined to assert its Lear right to challenge validity in order

86. 35 U.S.C. $\S \S 200-12$ (2006). The Bayh Dole Act encourages commercialization of university-generated inventions by giving universities the right to retain patents in federally funded research. For the importance of these license in that context, see, e.g., Posting of David Schwartz to the Tech Transfer Blog, Stanford Adds New Clauses to License Agreements in Wake of MedImmune Case, (June 4, 2008), http://www.technology transfertactics.com/content/2008/06/04/stanford-adds-new-clauses-to-license-agreements -in-wake-of-medimmune-case/.

87. For a discussion of the Bayh Dole Act, see Rebecca S. Eisenberg, Public Research and Private Development: Patents and Technology Transfer in GovernmentSponsored Research, 82 VA. L. REV. 1663 (1996); Arti K. Rai \& Rebecca S. Eisenberg, Bayh-Dole Reform and the Progress of Biomedicine, 66-SPG LAW \& CONTEMP. PROBS. 289 (2003).

88. Lita Nelson, From Bench to Bedside: The Changing Landscape of University Technology Transfer in Biotechnology, http://www.ibfconferences.com/ibf/control/ presentation/Lita\%20Nelson.pdf.

89. See generally Paul J. Heald, Transaction Costs and Patent Reform, 23 SANTA ClARA COMPUTER \& High TECH. L.J. 447, 457-58 (2007). 
to avoid paying royalties. But at this point, the public has little need for an unmuzzled licensee. Judicial review of the patent will occur when the infringer asserts invalidity as a defense to an infringement action brought by the patentee or by licensees who have the right to sue for infringement. Thus, the issue of the patent's validity will be raised no sooner than (and no later than) it would be raised under Lear, but without the complications involved in permitting a party to avoid the royalty provisions of a contract entered into after arms'-length negotiation. ${ }^{90}$

To put this another way, when the licensee's freedom to challenge the patent is curtailed, the public exchanges the benefit of an unmuzzled licensee for a different benefit - encouraging licensees to examine the strength of the patents they license at the time they negotiate their agreements. This examination should result in a fairer valuation, and-presumably-lower the price that the public pays for the invention (or its output) from an earlier point in time.

Of course, contractual freedoms are not unlimited. Licensing can certainly be used anticompetitively; the licensee and licensor can enter into agreements that are antithetical to the interests of the public. ${ }^{91}$ Accordingly, licenses, particularly agreements that waive public-regarding elements of federal law, must be evaluated with care. Hatch-Waxman settlements are a case in point. In these cases, generic drug manufacturers are paid not to challenge the patents on pharmaceutical products. Lower courts have approved these settlements on the ground that they produce certainty and avoid litigation costs. ${ }^{92}$ However, they raise the price of drugs and, hence, contribute to the growing cost of healthcare. ${ }^{93}$ Now that MedImmune has apparently decided that the interest in challenging patents outweighs the problems associated with proliferating patent litigation, perhaps the case for permitting these settlements should be reevaluated. ${ }^{94}$

90. Dreyfuss, supra note 30, at 703-05 (footnotes omitted).

91. Examples include the types of licenses that were once considered "No-Nos" by the Justice Department. See Rule, supra note 80.

92. See, e.g., In re Tamoxifen Citrate Antitrust Litig., 466 F.3d 187, 203 (2d Cir. 2006); Schering-Plough Corp. v. F.T.C., 402 F.3d 1056, 1075 (11th Cir. 2005); Valley Drug Co. v. Geneva Pharm., Inc., 344 F.3d 1294, 1304 (11th Cir. 2003) (rejecting antitrust challenges to settlements).

93. See, e.g., In re Cardizem CD Antitrust Litig., 332 F.3d 896, 911 (6th Cir. 2003) (finding a settlement to be a per se violation of the Sherman Act).

94. See C. Scott Hemphill, Paying for Delay: Pharmaceutical Patent Settlement as a Regulatory Design Problem, 81 N.Y.U. L. REV. 1553 (2006); see also Harry First, Controlling the Intellectual Property Grab: Protect Innovation, Not Innovators, 38 RUTGERS 
Another problem more pertinent to this discussion is informational. Potential licensees may, because of their own business expertise and experience, be in a better position to know about the technology at issue than an examiner in the PTO, but they are not necessarily in possession of full information. Some kinds of information are uniquely in the hands of the patent holder. For example, only the patent holder is likely to have evidence of the true date of invention or whether the patentee was the true inventor. ${ }^{95}$ Some third-party evidence, such as evidence of attempts to sell the invention more than a year before the patent application was filed, may be equally difficult to locate. ${ }^{96}$ Thus, any examination of the patent at the time the license is negotiated will be incomplete and will therefore not perfectly protect the public interest in a robust public domain. The bottom line is that while MedImmune may have cast doubts on the popular understanding of Lear, how far it allows parties to order their own relationship remains to be determined.

\section{FIVE APPROACHES TO LICENSING IN LIGHT OF MEDIMMUNE}

To make the question of the continued vitality of the 1960 s case lore concrete-and to examine the approaches patentees can take to resolving the problems that MedImmune poses--this Part discusses five types of licensing agreements. These arrangements vary in both their distributional and social ramifications. Each attempts to allocate back to the licensee some of the risk of patent invalidation, but as a consequence, each also redistributes the commercial risks associated with the profitability of the invention. Socially, these approaches vary in terms of the degree to which they leave the licensee free (and motivated) to challenge the patent. Approaches that give the licensee less freedom to challenge the patent during the lifetime of the license are in some ways more protective of the public interest than is Lear because-unlike the estoppel doctrine-they alert potential licensees to the restriction and thus encourage them to examine the patent prior to negotiating their licenses. The result is that these arrangements foster early challenge and reduce the period in which the public is forced to pay a supracompetitive price for the invention. At the same time,

L.J. 365, 390-98 (2007). Indeed, as of this writing, the Senate is considering a bill that would bar these settlements. See supra note 35 .

95. See 35 U.S.C. $\S 102(\mathrm{~g})$, (f) (2006). See, e.g., Benitec Austl., Ltd. v. Nucleonics, Inc., 495 F.3d 1340, 1349 (Fed. Cir. 2007). Significantly, in that case the Federal Circuit acknowledged the possibility that the patent was invalid, but held that the case was nonjusticiable even under MedImmune.

96. See 35 U.S.C. $§ 102(b)$ (2006). 
however, the more freedom licensees retain to challenge the patent, the more efficacious the challenge, for the licensee gains time to discover information (such as prior art or prior sales) that could be used to invalidate the patent.

How well any of these arrangements survives Lear depends, of course, on whether Lear and its companion, Brulotte, remain good law and on how broadly their mandates are interpreted. These five approaches, which could certainly be modified or amplified by the thoughts of creative licensing executives or business negotiators and their legal counsel, are (a) a paid-up license; (b) a license coupled with a consent decree; (c) an arbitration clause; (d) a clause adjusting royalties to either allow for a challenge or to reflect that a challenge was unsuccessful; and (e) a termination on challenge clause.

Apart from the paid-up license approach, all of these licensing proposals should be understood against the background (evident in the license at issue in MedImmune) that licensing agreements usually give the licensee an unfettered right to terminate the portion of the license dealing with patents-as opposed to any provisions dealing with trade secrets or knowhow-by simply giving notice. Usually, the licensee also has the right to stop paying royalties for activities under any patent held invalid by a final decision of a court (and not subject to appeal). In some cases these rights are explicitly bargained for, but in many cases they have simply become part of the standard "boilerplate" in typical license agreements. Both provisions provide the licensee some measure of relief if the licensed patent is invalidated by a third party. Accordingly, in most cases, licensees are not, strictly speaking, fully "muzzled."

\section{A. A Paid-up License}

Perhaps the most straightforward way for a patent holder to avoid the risks imposed by MedImmune, and to regain control over income derived from licensing, is to require the licensee to pay the full licensing fee upfront in a single lump sum payment. If economic conditions permit such an arrangement, the patent holder would secure compensation for the disposition of its rights, while the risk of invalidation and any subsequent decline in the value of the license would be borne by the licensee.

Straightforward as this approach might be, its utility is questionable from both a business and a social policy perspective. Small companies, and especially startups, will often not be in a position to pay out the full cost of the license at the beginning of the relationship. As important, even if the licensee is willing to assume the risk of invalidation, it may not be ready to pay a lump sum and assume all of the business risks associated 
with commercializing the invention. For its part, the patent holder may be concerned that the commercial value will be higher than projected, and that it will wind up conferring a windfall on the licensee.

The commercialization problems may, however, be less severe than they appear. As suggested earlier, in some circumstances, a package of stock and stock options can be designed to track the licensee's success utilizing the patented invention. Alternatively, unexpected differences in licensed activity from what the parties calculated at the time the compensation was originally set could be handled by providing for a lump sum payment and then adding two adjustment clauses. One would be an enhancement in payment, which would reflect any increase in the economic value projected at the time the compensation was originally set; the other would provide for a refund to the licensee if net revenues fall below the initially projected amount. These adjustment clauses could also be calibrated to various time periods. For instance, they could provide for additional royalty fee payments or refunds upon comparing the projected amount to the actual amount for some time period less than the life of the license, such as every five years.

As to cash-flow, licensees that lacked the funds to pay the upfront costs might instead provide for payment by negotiable instrument: that is, the licensee would issue a series of negotiable instruments at the time the license was entered into with maturity dates apportioned over the life of the license. If the patent holder needed funds immediately, it could negotiate these instruments without recourse (albeit, most likely at a discount). Furthermore, if the licensee were a small or thinly capitalized company, it could provide notes secured by its assets, including its rights under the license, to make the notes more readily negotiable. Of course, this would require an adjustment in the typical licensing terms to allow the license to be assigned by the holder of the note if there is a default. And it would only make sense if arrangements were made so that if there were a default, there would be only one party holding a security interest in the license able to immediately seize the license or asset. But that could also be arranged: all of the notes could be negotiated together or a single note could include several maturity dates. In either case, the license should also include an acceleration clause for default on any note or installment.

Another alternative is a license providing for a series of payments over time without regard to licensed activities. This would be a firm contractual obligation entered into at the time the license was granted which should be independent of any later determination with regard to the validity of the licensed patents. 
These approaches would ameliorate some of the discomfort that both parties might feel in projecting the revenue likely to accrue over the life of the licensed patents, but they too are not without their problems. Depending on the size of the lump sum payment, the patent holder will still run considerable risk that compensation for the invention will fall short of the benefit it confers on the licensee. The licensee will not challenge the patent if actual earnings are lower than projected earnings because it will want its refunds. On the other hand, if the actual earnings are greater than the projected return, the licensee could very well decide to challenge. If the patent is invalidated, it is possible that a court will view the payment adjustment as a species of running royalty, and not require the licensee to continue to pay. Indeed, negotiable instruments, if still in the hands of the patent holder, might also be vulnerable to challenge in that circumstance.

Even a one-shot, lump sum payment will likely be lower than the net present value of the projected running royalty. Typically, the net present value of the projected royalty stream would be calculated using an anticipated discount based on the projected time value of money over the life of the license. The patent holder would have to reduce his price to reflect the benefit to him of this particular arrangement. This "bargain" price would arise from shifting some of the risk of patent invalidity from the patent holder to the licensee: the price would reflect the risk, assumed by the paid-up licensee, that after paying the lump sum, the licensed patent would be invalidated by a third party. The discount would likely be considerable: not only would the licensee have paid for an unnecessary license under an invalid patent but it would be at an economic disadvantage compared to its competitors in the licensed field who had not paid such a lump sum and therefore do not need to recover it in their sales price.

From the perspective of federal patent policy, this arrangement is also somewhat dubious. Because running royalties are the standard way of allocating benefits, paid-up licenses would be utilized only if Lear remains good law. But if it is good law, then a paid-up license could be viewed as frustrating the "private attorney general" policy underlying Lear. After all, once the licensee has paid for the right to practice the invention, it is less likely to challenge the patent. Indeed, if it is an exclusive licensee, the probability that it will destroy its own competitive advantage is close to zero.

But this problem may also be somewhat more attenuated than it initially appears. Requiring the licensee to pay the entire value of the license upfront provides it with formidable incentives to investigate the patent very carefully. If the potential licensee harbors any doubts about the patent's validity, it will either ignore the patent (which would benefit the public by 
lowering its costs of doing business), or it will require a substantial discount in the licensing fee (which would, again, lower the cost of doing business), or-now that MedImmune appears to have opened the courthouse door - it will bring a declaratory judgment action (and provide the public with the benefit of free use of the invention). Not only would early scrutiny lead to sooner invalidation of the patent, a party facing the prospect of paying high fees has more incentive to challenge the patent than does a licensee (especially an exclusive licensee).

The paid-up license approach may also be viewed as incompatible with Brulotte. That is, a court may be concerned that the economic disadvantages endured by the licensee (loss of startup funds and continuing installment payments) violate the principle that inventions that are not patented are free to use. But as suggested in Part II, there are strong reasons to believe that Brulotte is no longer good law. Unless the patent has considerable market power, there is no reason to think that the licensee agreed to pay more than the invention was worth or that it failed to bargain for a discount to account for the possibility that a third party would invalidate the patent. Furthermore, the arrangement has a substantial benefit: a lower fee is attractive, especially to thinly capitalized entrepreneurs and to startup companies.

Nonetheless, the approaches that use negotiable instruments or installments may appear particularly vulnerable to a Brulotte challenge because in those cases, it is evident that payments will continue even if the patent is invalidated by a third party. But even here, the benefits of the arrangement are clear. Essentially, these options, which delay the time when payment is due, provide the licensee with a loan to help finance its commercialization efforts. Spreading out the cost of the license over a longer period of time is thus efficient because it reduces deadweight loss. ${ }^{97}$ Significantly, since Brulotte was decided, the Court upheld an arrangement requiring payments beyond the patent term. In Aronson v. Quick Point Pencil Company, negotiations took place while the patent application was pending. Anticipating the possibility that the patent would be rejected, the

97. See, e.g., FTC \& Dep't of Justice, Antitrust Enforcement and Intellectual Property Rights: Promoting Innovation and Competition 12 (2007). The report concluded that: [c]ollecting royalties beyond a patent's statutory term can be efficient. Although there are limitations on a patent owner's ability to collect royalties beyond a patent's statutory term, that practice may permit licensees to pay lower royalty rates over a longer period of time, which reduces the deadweight loss associated with a patent monopoly and allows the patent holder to recover the full value of the patent, thereby preserving innovation incentives.

Id. (citation to Brulotte omitted). 
license provided for one royalty rate if the patent issued and another if it did not. ${ }^{98}$ After the patent failed to issue, Quick Point sued for a declaration that it was not obliged to continue to pay royalties. It lost. The Court rejected the leverage theory that supported Brulotte $e^{99}$ and suggested that the agreement created added incentives to innovate and transfer technology. ${ }^{100}$ Finally, it noted that Brulotte was not unfair to the public or to the licensee. The public had free use of the invention after it was disclosed. ${ }^{101}$ And Quick Point had notice that it would be bound by the agreement even if no patent issued:

[T] he parties contracted with full awareness of both the pendency of a patent application and the possibility that a patent might not issue. The clause de-escalating the royalty by half in the event no patent issued within five years makes that crystal clear. $^{102}$

In a concurrence, Justice Blackmun even posited that Brulotte had been overruled. ${ }^{103}$ And both lower courts and the Federal Trade Commission have suggested that it ought to be reconsidered. ${ }^{104}$ Notably, although courts have hesitated to ignore Brulotte, there is case law to suggest that installment payments remain due even if the licensed patent is invalidated. ${ }^{105}$

\section{B. A License Coupled With a Consent Decree}

Although there are ways in which a paid-up license fulfills the goals of Lear better than does Lear, it suffers from two serious problems. First, there is the information deficit issue noted at the end of Part II. Because

98. Aronson v. Quick Point Pencil Co., 440 U.S. 257 (1979).

99. Id. at $264-65$.

100. Id. at $262-63$.

101. Id. at 263 .

102. Id. at 261 .

103. Id. at 266-67 (Blackmun, J., concurring).

104. See, e.g., Zila, Inc. v. Tinnell, 502 F.3d 1014, 1019-20 (9th Cir. 2007) (questioning, but applying, Brulotte); Scheiber v. Dolby Labs., Inc., 293 F.3d 1014, 1017-19 (7th Cir. 2002) (questioning, but applying, Brulotte); FTC \& DEP'T OF JUSTICE, supra note 97, at 117; see also Michael Koenig, Patent Royalties Extending Beyond Expiration: An Illogical Ban From Brulotte to Scheiber, 2003 DUKE L. \& TECH. REV. 5.

105. See Ransburg Electro-Coating Corp. v. Spiller \& Spiller, Inc., 489 F.2d 974, 978 (7th Cir. 1973) (holding that installment payments for past activities were due despite invalidation of the underlying patent); see also Zenith Radio Corp. v. Hazeltine Research, Inc., 395 U.S. 100, 138-39 (1969) (commenting favorably on the approach in Automatic Radio Mfg. Co. v. Hazeltine Research, Inc., 339 U.S. 827 (1950), that a lump sum payment which was not tied to actual use of the licensed patent was not objectionable). 
licensees lack the capacity to acquire information uniquely in the hands of patentees and may also have difficulty finding information in the possession of third parties, an early evaluation of validity is likely to be imperfect. Indeed, one reason that patents never become incontestable is that invalidating information can arise after examination. ${ }^{106}$ In some cases (MedImmune is an example), the license is negotiated before the patent issues - that is, before the PTO completes its assessment. Second, a general move to paid-up licenses could have a deleterious impact on technological progress. Without running royalties, it is difficult to adjust the price of the license to reflect experience with the invention. Since there is an ever-present likelihood that it is the patent holder's income that will be diminished, incentives to innovate may be reduced.

These problems would, however, be ameliorated if the parties made a running-royalty license part of the settlement of a legal proceeding in which the validity of the patents to be licensed was or could have been put into issue. Typically this would mean that the parties would have to reach a tentative licensing agreement, and then, either the patent holder would bring a patent infringement suit or the licensee would institute a declaratory judgment action. In either event, the licensing agreement would eventually become part of a consent decree terminating the dispute. If the decree were entered by a court that had proper jurisdiction, any challenge to it - including challenge to the validity of the underlying patent-would be a collateral attack, presumably forbidden by res judicata. Accordingly, the consent decree should foreclose challenge by any party to the proceeding or its privities and perhaps even by any party claiming a benefit under the license. ${ }^{107}$ Since courts, in our experience, appear to take little interest in the exact terms of these agreements, the parties might even be permitted to agree to running royalties during the entire time the patented invention is worked by the licensee. If the potential licensee were given a forum in which it could fully explore any validity issues in which it had an interest and in which it could enjoy access to the full panoply of discovery devices, including the right to examine the patent holder's files and subpoena third parties, then concerns about lack of information would abate, as would the problems that animated the Lear and Brulotte Courts. As noted earlier, courts have upheld such arrangements, even against antitrust challenges in the Hatch-Waxman context. ${ }^{108}$

106. Cf. 15 U.S.C. $\S 1065$ (2006) (defining incontestability of trademark rights).

107. See, e.g., Am. Equip. Corp. v. Wikomi Mfg. Co., 630 F.2d 544, 548 (7th Cir. $1980)$.

108. See supra note 92 and accompanying text. 
This arrangement may, however, have limited applicability. First, there is some danger to the patent holder that the licensee will change its mind and proceed with the lawsuit instead of entering into a settlement. After all, the ability to actually use discovery and proceed before the court is what distinguishes the proceedings from sham litigation and gives legitimacy to the consent decree. Since, under MedImmune, the patent holder can no longer use a covenant not to sue as a way to have a losing case dismissed, ${ }^{109}$ this approach requires the patent holder to assume the risk that the patent will be invalidated at a very early stage in its life, before the patent holder can earn a return on its investment or inventive efforts. This danger is, however, unlikely to be acute. The cost of litigating a case to judgment is extremely high and creates a significant deterrent to walking away from a deal. Unless there was a dramatic change in the commercial landscape after the parties negotiated the tentative license terms, the license is likely to continue to be economically attractive to the licensee.

More important are problems of timing and expense. Given the crowded dockets in most federal courts, procedural skirmishes could lead to unacceptable delay in consummating the license. Moreover, while $\mathrm{Me}$ dImmune took a liberal attitude toward the availability of declaratory judgment actions in patent cases, it did not abolish all standing and ripeness requirements. Accordingly, before either of the parties could bring an action, it would probably be required to demonstrate, at the very least, that the licensee had already engaged in infringing activity or had made substantial preparation to do so. ${ }^{110}$ Although the defendant in the action would certainly avoid asserting standing and ripeness defenses, a court concerned with a lack of adversariness could raise the justiciability question on its own motion. ${ }^{111}$ And even if the court did not identify the problem, the decree it issued might not be particularly useful to the patent holder because an overly friendly suit-for example, a suit that was settled before the licensee actually used its discovery opportunities-will not

109. See, e.g., Honeywell Int'l Inc. v. Universal Avionics Sys. Corp., 488 F.3d 982, 995 (Fed. Cir. 2007).

110. See, e.g., Prasco LLC v. Medicis Pharm. Corp., 537 F.3d 1329, 1339-40 (Fed. Cir. 2008) (requiring that the plaintiff to show an affirmative act by the patentee demonstrating an intent to sue); $c f$. Janssen Pharmaceutica, N.V. v. Apotex, Inc., 540 F.3d 1353, 1362-63 (Fed. Cir. 2008) (requiring more than speculative fear of harm to establish that the dispute is "definite and concrete").

111. Cf. FED. R. CIV. P. 12(h)(3) (subject matter objections can be raised by the court sua sponte). 
likely bind sublicensees and other parties allegedly in privity with the licensee. $^{112}$

The parties could alternatively try to save time and money by settling the case between themselves and then jointly petitioning the court to dismiss the proceedings without seeking a consent decree. Although some courts have enforced no-contest clauses in such agreements when they encounter them as defenses to patent challenges mounted by licensees, ${ }^{113}$ not all courts respect them; judges may be particularly reluctant to recognize such clauses if the parties settled before the licensee engaged in discovery. ${ }^{114}$ Furthermore, without the imprimatur of the court, it is difficult to know what constitutes a settlement and what is merely the culmination of negotiations to license the patent. Genentech, for example, tried to characterize the license with MedImmune as a settlement. ${ }^{115}$ Furthermore, even if a court were inclined to enforce the terms of a settlement against the licensee, it would be highly unlikely to hold anyone else bound by it.

\section{An Arbitration Clause}

While the consent decree approach may comply with federal patent policy, it utilizes federal court resources in ways that might be considered objectionable - for a trumped up suit that is not designed to produce the public benefit of releasing the invention into the public domain. Instead, the parties could assume the costs of testing the patent by agreeing to arbitrate disputes concerning validity and infringement. Under this approach, the license would be structured to meet the parties' business needs and could include running royalties, but instead of leaving the licensee free to challenge the patent in court as contemplated by Lear and MedImmune, the licensee would instead be required to arbitrate.

This approach has benefits and drawbacks as both a private and a social matter. On the business side, it rights the imbalance created by $\mathrm{Me}$ dImmune. So long as the parties agree to keep the record of the arbitration-including any evidence presented and any arguments made to the

112. See, e.g., Hansberry v. Lee, 311 U.S. 32, 43-44 (1940) (noting that requirements of due process and full faith must be satisfied for a nonparty to be bound); $c f$. Taylor v. Sturgell, 128 S. Ct. 2161, 2173-74 (2008) (rejecting the theory of virtual representation).

113. See Dreyfuss, supra note 30, at 720; see, e.g., Flex-Foot, Inc. v. CRP, Inc., 238 F.3d 1362, 1370 (Fed. Cir. 2001) (holding that the licensee is contractually stopped from challenging the validity of the patent "[b]ased on the clear and unambiguous waiver of future challenges to the validity of the ... patent in the settlement agreement").

114. See Dreyfuss, supra note 30, at 720; see, e.g., Warrior Lacrosse, Inc. v. Brine, Inc., No. 04-71649, 2006 WL 763190, *26 (E.D. Mich. Mar. 8, 2006). See generally Cooley Alert!, supra note 57.

115. Transcript of Oral Argument, supra note 67, at 29. 
tribunal-confidential, then even a successful challenge will not invalidate the patent or even provide information to other licensees, potential licensees, or possible challengers. ${ }^{116}$ As a result, the parties would be on a more equal footing: the patent holder would not be put into the position of risking the entire value of the patent in the dispute resolution. This arrangement also gives the parties the opportunity to structure the procedures to meet their needs. For example, if the parties are concerned about resources, they could limit discovery and the overall length of the proceeding. Alternatively, a licensee worried about its capacity to obtain sufficient information could bargain for the use of specific discovery tools or reserve the right to utilize judicial proceedings on issues - such as inequitable conduct and the on-sale bar-which are not easily developed in an arbitration proceeding.

Admittedly, there are some disadvantages to arbitration, but they are not particularly severe. For the patent holder, one disadvantage is that arbitration is generally cheaper than litigation (and, as noted above, can be made cheaper still). Accordingly, there is a risk that the reduced cost will make the licensee too ready to challenge the patent. However, because arbitration awards bind only the parties, ${ }^{117}$ the arbitration clause will still protect the patent holder from the danger that third parties will benefit from an invalidity decision. Of course, matters submitted to an arbitrator can wind up in court. As discussed previously, the parties can agree to litigate particular issues and one or the other side may seek to overturn the arbitral decision ${ }^{118}$ or enforce it. Judicial decisions are presumptively public, but they can be sealed when confidentiality is warranted. ${ }^{119}$ For the licensee, the main problem is that the arbitrator may be more deferential to the PTO than judges, making it less likely that a challenge to the patent will win. But, again, the problem does not appear to be acute.

The compatibility of this approach with federal patent policy is, however, somewhat difficult to reckon. Although arbitration makes it less onerous for the licensee to avoid its obligations under the license, the pub-

116. Notice that the parties have settled an arbitration must, however, be made public, under 35 U.S.C. $\$ 294$ (2006).

117. 35 U.S.C. $\$ 294(c)$.

118. See 9 U.S.C. $\S 10$ (2006) (giving district courts authority to vacate an award that is procured by fraud, corruption, misconduct or bias, or the arbitrators exceeded their powers). See generally Karl P. Kilb, Note, Arbitration of Patent Disputes: An Important Option in the Age of Information Technology, 4 FordHAM. INTELL. PROP. MEDIA \& ENT. L.J. 599, 619-21 (1993).

119. See, e.g., Commercial Union Ins. Co. v. Lines, 239 F. Supp. 2d 351, 358 (S.D.N.Y. 2002) (holding that a sufficient showing of a need for confidentiality was not made in that case). 
lic need not be informed about the nature of the arbitral award. Accordingly, Lear's goal of putting advances that should not be patented into the public domain will be frustrated. On the other hand, the Patent Act explicitly provides that parties may agree to arbitrate disputes regarding validity and infringement; it also provides that the parties are bound by the arbitral award. ${ }^{120}$ The availability of binding arbitration for patent invalidity challenges suggests that while Lear might require the licensee to be free to defend its own interests in invalidating wrongfully issued patents, federal policy does not always require the licensee to simultaneously protect the public interest by releasing inventions for free public use. ${ }^{121}$ Nor does it restrict adjudication of validity to the federal judiciary.

\section{A Clause Adjusting the Royalty Either to Reflect or Permit a Challenge}

If arbitration is considered insufficient protection for the licensee or the public interest, another solution is to use licensing agreements that include a provision adjusting the royalty rate to reflect validity challenges. One approach is to provide in the license agreement that the licensee may challenge at will, but also provide for an increase in the royalty rate should the challenge be unsuccessful. A second idea is to establish a three-tier system, with the rate increasing once a challenge is mounted, and providing for an even higher royalty if the challenge is not successful. ${ }^{122}$ Both arrangements solve the MedImmune problem because they increase the risk to the licensee, thus putting it on a more equal footing with the patent holder.

The first approach - a different royalty for patents that have survived challenge - gives the licensee a full and fair opportunity to challenge the patent whenever it finds information suggesting that the patent is invalid. Although the increase in the rate creates a disincentive and may seem in-

120. 35 U.S.C. $\$ 294$.

121. There are other ways in which federal policy reduces patent challenges. For example, in Benitec Austl., Ltd. v. Nucleonics, Inc., 495 F.3d 1340, 1348-49 (Fed. Cir. 2007), the declaratory plaintiff possessed evidence of invalidity. Nonetheless, the court held the case nonjusticiable under the new standard imposed by MedImmune. In some ways, the Blonder-Tongue decision has a similar effect. See generally Blonder-Tongue Labs., Inc. v. Univ. of Ill. Found., 402 U.S. 313 (1971). It discourages suit because it puts the challenger at a competitive disadvantage with respect to everyone else in the field of the invention: that party must pay the full litigation cost of invalidating the patent while its competitors enjoy the outcome for free. As a result, there is an incentive to hold back, to wait and see whether someone else will do the hard work of putting the invention into the public domain.

122. In fact, Stanford University has already announced that it will use this approach. See Schwartz, supra note 86. 
consistent with Lear, patents that have survived a challenge are generally perceived by the business community as more valuable than untested patents. Accordingly, the higher rate should be regarded as reflecting the economics of the relationship, rather than as a penalty for challenging the patent. In some ways, it too is similar to the licensing arrangement approved in Aronson, where the Court emphasized that the licensee was paying for the value that it had received. ${ }^{123}$ Furthermore, the different rate does not entirely eliminate the incentive to challenge: if the challenge is successful, the licensee will terminate the license and escape the obligation to pay royalties. At the same time, the risk of incurring a more costly obligation increases the licensee's motivation to investigate the patent before negotiating a license. As noted earlier, if the potential licensee determines the patent is invalid, it will ignore the patent or insist on a lower licensing fee. Either way, the public benefits from lower costs during the interval before the patent expires or is successfully challenged.

Much the same can be said of the further option, requiring a higher royalty during the time when the case is being adjudicated. Since the pendency of patent litigation can be quite lengthy, ${ }^{124}$ this option erects quite a strong disincentive to sue. On the other hand, it also creates a strong incentive to investigate the patent prior to licensing it. In addition, this option is economically justified. Patent litigation is not only lengthy, it can also be very expensive. ${ }^{125}$ Imposing an increased royalty during the period of challenge defrays the additional economic burden defending such a challenge imposes on the patent holder. Especially in emerging sectors where many of the licensees cannot afford high fees at the outset of the relationship, this approach is preferable to setting a high royalty rate on all licensees to cover the potential expense of defending a challenge.

There is also another alternative along these lines: a license can be offered at two different rates, depending on whether the licensee wishes to retain the right to challenge the patent. As to Lear, the analysis here is much like the one suggested above: the licensee is muzzled by the contract, but has greater incentives to vet the patent prior to licensing. As a

123. Aronson v. Quick Point Pencil Co., 440 U.S. 257, 263 (1979).

124. See, e.g., Jay P. Kesan \& Gwendolyn G. Ball, How Are Patent Cases Resolved? An Empirical Examination of the Adjudication and Settlement of Patent Disputes, 84 WASH. U. L.R. 237, 282 (2006).

125. See, e.g., R. Polk Wagner, The Supreme Court and the Future of Patent Reform, 55 FED. LAW. 35, 36-37 (2008) (observing that for "litigation with less than \$1 million at risk, litigation fees from initiation of the lawsuit through appeal were $\$ 500,000$; with $\$ 1$ million to $\$ 25$ million at risk, the fees rose to just over $\$ 2$ million; and when more than $\$ 25$ million is at stake, litigation expenses approached $\$ 4$ million”). 
business matter, however, this arrangement will only make sense for the patent holder if the license is exclusive. If the license is nonexclusive, then once one licensee opts for preserving the ability to challenge (and agrees to pay at the higher rate), others may well opt for the lower rate, knowing that they can always terminate their agreements in the event that the licensee with the right to challenge does so successfully.

To counter that possibility, the patent holder could couple the lower rate with an obligation to pay for the full term of the patent regardless of any invalidation - that is, with a refusal to permit the licensee to terminate at will. Such a measure could, however, run into an objection based on Brulotte. But as noted earlier, there are many reasons to believe that Brulotte is no longer good law. Furthermore, just as in Aronson, where a dualrate contract helped the Court understand why, as a general matter, concerns over leverage are misplaced, the differential rate here provides concrete evidence that risk allocation matters; if a licensee is willing to accept the risk of invalidation, it can enjoy the benefits of the patent at a lower rate. In fact, the greater differential between the two licensing rates-that is, the more the royalty is reduced for those licensees who are willing to forgo a challenge - the more credible the argument that there is a social benefit to the arrangement. Indeed, this approach should be of special interest to entrepreneurs at the technological frontier: to startup patent holders and universities who want to lock in an income stream without sacrificing the opportunity to utilize running royalties to allocate the business risks associated with commercialization, and to thinly capitalized licensees, who need to lower the cost of licensing.

\section{E. A Termination-on-Challenge Clause}

In some ways, the best way to deal with MedImmune is for the patent holder to bargain for the right to terminate the license should the licensee choose to challenge the validity of the patent. With respect to litigation risks, this would fully restore the parties to the pre-MedImmune situation. It has the further benefit of harmonizing U.S. licensing practices with those of other countries. Indeed, in Europe, where there are no standing requirements for bringing actions to nullify a patent, termination-onchallenge clauses are routinely used to protect licensors from legal actions on the part of licensees. Significantly, although EU competition guidelines prevent licensors from requiring licensees to forbear from challenging pa- 
tent validity, the European Commission has found termination-onchallenge clauses compatible with competition guidelines. ${ }^{126}$

A termination provision must be carefully drafted to maximize the patent holder's options. It should not provide for automatic termination, but, rather, for an option to terminate. This is because there will be cases in which the patent holder will want the license to remain in force. For instance, if the license continues, the patent holder can characterize the case as a contract dispute, and bring the action in state (rather than federal) court. ${ }^{127}$ The contract should also be structured to fully protect the patent holder by providing that the option is triggered if the licensee provides direct or indirect aid to a third party in challenging any of the licensed patents. It should also extend to a challenge to any of the licensed patents whether US or foreign, and to a challenge via any official proceeding, be it an opposition, a nullity suit, a reexamination, an interference, or a declaratory judgment action.

If such a provision is contemplated, care should also be taken not to refuse to separately license any unrelated patents included within the license. Otherwise, the licensor may be accused of unfairly protecting weaker patents from attack by bundling them with stronger patents. However, it is quite reasonable to insist that all the members of a patent family be licensed together, since an attack on the validity of one of them would likely impact the validity of the rest of the family - that is, it can be expected that arguments brought against one family member are likely to be pertinent to other members of the same family. ${ }^{128}$

The compatibility of this provision with federal policy is, clearly, the hardest to determine. The MedImmune and Lear Courts did not consider the issue because until MedImmune was decided in 2007, no such clause

126. See Commission Regulation 772/04, 2004 O.J. (L 123) 5(1)(c); Commission Notice (EC) 2004/C 101/02, 2004 O.J. (C 101), 112, 113.

127. Lear was such a case: the action was initially filed in the California Superior Court. See Lear, Inc. v. Adkins, 395 U.S. 653, 660 (1969).

128. From the patent holder's perspective, it would be highly desirable to allow for termination if any member of the family of the patent was challenged, even if the challenged member was not part of the licensing agreement. Otherwise, the licensee might be able to avoid the termination provision by taking rights in one set of countries and then challenging the counterpart in a country where the patent is not covered by the license. Although a successful challenge will theoretically leave the licensed patents intact, as a practical matter, a successful challenge will induce others to infringe and reduce the value of the patent holder's assets. At the same time, the more limited the termination clause, the more easily it can be distinguished from the license found unenforceable in Pope Manufacturing Co. v. Gormully, 144 U.S. 224 (1892), which involved a direct promise not to bring a challenge at all. See supra note 70 . 
was considered necessary. Rather, it was assumed that licensees who chose to challenge were required to give up the benefits of the license. ${ }^{129}$ As Part II suggested, MedImmune can certainly be read as intending to take the safeguards offered in Lear one step further, to free all licensees to challenge the validity of the licensed patent. But so much has changed since Lear, it makes more sense to read the absence of a discussion of this issue in MedImmune as an invitation to rethink the received wisdom of Lear. The law at the interface between federal and state law has substantially changed since Lear was decided and economists and antitrust courts no longer regard patentees as enjoying the leverage necessary to demand concessions that are not economically justified. Furthermore, the need to rely on licensees as private attorneys general has largely waned: there are now new ways to challenge patent validity inexpensively within the PTO ${ }^{130}$ To some extent, even worries about the operation of the PTO-in particular, the "notorious" differences between the law as applied by the patent office and the law applied by the regional courts ${ }^{131}$ - have dissipated through the establishment of the Federal Circuit. ${ }^{132}$ Certainly, there are reasons to be concerned about that court's jurisprudence. However, unmuzzling licensees will only bring more cases before that court; it will not necessarily improve its decision-making.

This discussion leaves one other option on the table: the no-contest clause for which Justice Scalia appeared to be looking. Certainly, an argument could be made that no-contest clauses should be as enforceable as the approaches discussed above. So long as they are clear, they give the licensee notice that the time to assess the validity of the patent has arrived. Thus, they promote early entry into the public domain of advances that should never have been patented. At the same time, however, the discussion in Part III demonstrates that it is possible to equalize both the litigation and commercialization risks between the parties - that is, to permit challenges while facilitating payment options that enable continuous evaluation of the benefits of the patent-without completely sacrificing the right to challenge the patent. Furthermore, as a key prerequisite for allowing patent holders to extinguish the licensee's right to challenge after a

129. See, e.g., Gen-Probe Inc. v. Vysis, Inc., 359 F.3d 1376, 1381 (Fed. Cir. 2004); Cordis Corp. v. Medtronic, Inc., 780 F.2d 991, 993 (Fed. Cir. 1985).

130. See supra note 34 and accompanying text.

131. Graham v. John Deere Co., 383 U.S. 1, 18 (1966).

132. At the time of Lear, district court patentability rulings were reviewed by regional appellate courts, while the patent office's decisions were reviewed by the Court of Customs and Patent Appeals. In contrast, the Federal Circuit hears appeals from both the PTO and courts. See generally Rochelle Cooper Dreyfuss, The Federal Circuit: A Case Study in Specialized Courts, 64 N.Y.U. L. REV. 1 (1989). 
license is signed, the licensee must have had the ability to challenge the patent before entering into the license. Yet some of the Federal Circuit cases subsequent to MedImmune suggest the court is backsliding by once again, requiring the declaratory plaintiff to show an apprehension of suit. ${ }^{133}$ If that is so, then it will be important to give licensees some degree of flexibility. After all, MedImmune also suggests that there is no strong federal interest in avoiding litigation. As the Hatch-Waxman cases illustrate, there are circumstances where the public interest may be best served by preventing the patent holder from completely muzzling a party in a particularly strong position to challenge the patent.

\section{CONCLUSION}

In many ways, MedImmune was an excellent decision. In striking the Federal Circuit's apprehension-of-suit requirement, the Court put an end to the practice of using patents of dubious quality to stifle competition. With good reason, however, MedImmune was greeted with considerable alarm by the licensing community. By permitting licensees to remain in good standing while attacking the validity of the patents they are working, MedImmune creates a difficult imbalance in the relative bargaining positions of patent holders and licensees. This asymmetry is likely problematic in all parts of the economy, but it is particularly troublesome in emerging sectors, like biotechnology, where the criteria for patentability are unsettled and many of the participants are thinly capitalized. For start-up licensors and universities, the bargaining asymmetry, coupled with the inability to assure a steady income stream is especially worrisome. And if licensors shift to a system of paid-up licenses, then there will be potential licensees priced out of the market.

But even here, MedImmune could represent a blessing, albeit in disguise. The decision could lead courts to revisit Lear, Brulotte, and the other 1960 s cases expressing distrust with state law that touches on innovation policy. Lear and Brulotte were likely misguided when they were decided and they are certainly out of step with current economic understanding and business practices. Rules that give licensing parties greater flexibility to structure their arrangements can make licensing more efficient, improve public access to new technologies, and enhance incentives to innovate.

This is not, however, to say that MedImmune should be read as giving parties full autonomy to structure their relationships at will. By opening

133. See supra note 110. 
the courthouse door to licensees in good standing, it suggests that avoiding litigation is not a core social goal. Thus, agreements-such as HatchWaxman settlements - that restrain competition in the name of saving litigation costs likewise deserve fresh scrutiny. 
BERKELEY TECHNOLOGY LAW JOURNAL 